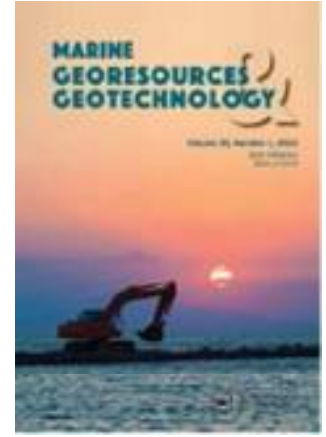

\title{
Modelling the cross-shore profiles of sand beaches using Artificial Neural Networks
}

\begin{tabular}{|r|l|}
\hline Journal: & Marine Georesources \& Geotechnology \\
\hline Manuscript ID & UMGT-2018-0074.R1 \\
\hline Danuscript Type: & Original Article \\
\hline Complete List of Authors: & $\begin{array}{l}\text { López, Isabel; Universitat d'Alacant, } \\
\text { Aragonés, Luis; Universitat d'Alacant } \\
\text { Villacampa, Yolanda; Universitat d'Alacant }\end{array}$ \\
\hline Keywords: & $\begin{array}{l}\text { Artificial Neural Network, sand, beach profile, profile slope, Posidonia } \\
\text { oceanica }\end{array}$ \\
\hline \\
\hline $\begin{array}{l}\text { Note: The following files were submitted by the author for peer review, but cannot be converted to } \\
\text { PDF. You must view these files (e.g. movies) online. }\end{array}$ \\
\hline Figure_5.jpg
\end{tabular}

\section{SCHOLARONE*}

Manuscripts 


\section{Modelling the cross-shore profiles of sand beaches using Artificial Neural Networks}

Isabel López ${ }^{\left(\mathrm{a},{ }^{*}\right)}$, Luis Aragonés ${ }^{(\mathrm{b})}$, Yolanda Villacampa $^{(\mathrm{c})}$

${ }^{\left(a,{ }^{*}\right)}$ Isabel López. Corresponding Author. Email: isalopu.il@gmail.com. Department of Civil Engineering. University of Alicante. 03690, San Vicente del Raspeig, Spain.

(b) Luis Aragonés. Email: laragones@ua.es. Department of Civil Engineering. University of Alicante. 03690, San Vicente del Raspeig, Spain.

(c) Yolanda Villacampa. Email: villacampa@ua.es. Department Applied Mathematics. University of Alicante. 03690, San Vicente del Raspeig, Spain.

\section{ABSTRACT}

Artificial Neural Networks (ANN) have been widely used successfully to solve coastal engineering problems. In this article they are used to model the cross-shore profile of sandy beaches taking into account the possible effect of marine vegetation (Posidonia oceanica). Sixty ANNs were generated by modifying both the inputs and the number of neurons in the hidden layer. The best results were obtained with the following inputs: wave height perpendicular to the coast and the associated period and probability of occurrence, median sediment size, profile slope, and energy reduction factor due to Posidonia oceanica. With these inputs and 10 neurons in the hidden layer, a mean absolute error of $0.22 \mathrm{~m}$ during training and $0.21 \mathrm{~m}$ during the test was obtained, which represents an improvement of 81.2\% and 55.5\% compared to models without and with Posidonia oceanica.

Keywords: Artificial Neural Network; Sand; Beach Profile; Profile slope; Posidonia oceanica 


\section{Introduction}

Beach erosion is a very serious problem around the world (Allen 1981; Semeoshenkova and Newton 2015; Pranzini, Wetzel, and Williams 2015). To address this problem, it is important to know the morphology and morphodynamics of the area of study (Larson and Kraus 1995), which is mainly controlled by wave climate, tide and sediment characteristics (Bernabeu, Medina, and Vidal 2003; Boon and Green 1988). Therefore, numerical simulations of hydrodynamics, sediment transport and morphological changes is essential for coastal management, planning and maintenance (Chen et al. 2015; Keshtpoor et al. 2015). Because of the influence of tidal currents, freshwater discharge, waves and the interaction between them on the hydrodynamics of tidal inlets, they are often highly dynamic environment sand have complex hydrodynamics, resulting in equally complex sediment transport and morphological changes (Sedigh et al. 2016).

Another important factor in determining the cross-shore beach profile is the presence of marine vegetation. In the case of the Mediterranean, the marine phanerogamous Posidonia oceanica stands out (Medina, Tintore, and Duarte 2001), and cover about $1.5 \%$ of the total Mediterranean Sea surface (Pasqualini et al. 1998). Posidonia oceanica meadows are usually recorded from near the surface to $40 \mathrm{~m}$ depth, but living plants have been found as deep as $48 \mathrm{~m}$ in particularly clear waters (Boudouresque et al. 1994; Pergent-Martini et al. 2005). This species loses leaves in autumn that form large litter patches in the surf zone and huge litter banks on adjacent beaches, resulting in wedge and layered structures of few centimetres to several meters in thick (Gómez-Pujol et al. 2013).This marine plant affects the profile due to its capacity to reduce wave energy by friction between the water and the beams (Méndez, Losada, and Losada 1999; Koftis and Prinos 2012), as well as by the retention and stabilization of sediments causing a more vertical transverse profile (Gacia, 
48

49

50

51

52

Granata, and Duarte 1999). Several experiments have confirmed that the Posidonia ocecanica meadows reduce wave energy, especially for low energy, low amplitude waves, which improves sediment stabilization in relation to areas without vegetation (Manca et al. 2012). However, during storms (high energy), they offer almost no protection (Vacchi et al. 2017).

The modelling of coastal profiles began in the 1950s with simple mathematical equations (Bruun 1954; Dean 1977; Vellinga 1983; Vellinga 1984). While mathematical and numerical process-based models are now used that can incorporate a large number of parameters and even hydrodynamic models (Masselink and Li 2001; Stive and de Vriend 1995; Aragonés et al. 2016; Neill, Elliott, and Hashemi 2008; Ranasinghe et al. 2004). However, due to uncertainties in understanding nearshore processes (wave breaking, wave reflection, refraction, diffraction and sediment transport) there are still important discrepancies between model results and measured data (Iglesias et al. 2009). Accordingly, other methods such as Artificial Intelligence (AI) have been introduced in this area, which are less expensive compared with physical-based numerical models (Hashemi, Ghadampour, and Neill 2010).

Al is based on learning through data, that is, it is necessary to know the variables (wind, waves, sediment, etc.) but not the processes precisely, so it is a useful tool in coastal applications (Bernabeu, Medina, and Vidal 2003; Hashemi, Ghadampour, and Neill 2010). In recent years, Al techniques such as artificial neural networks (ANNs) have been successfully applied to coastal engineering problems (Iglesias et al. 2009; Huang et al. 2003; Ghorbani et al. 2010; López, Aragonés, Villacampa, and Serra 2017; Demirci, Üneş, and Aköz 2015).

In addition, some authors have used neural networks to determine the submerged (López, Aragonés, Villacampa, and Compañ 2017; van Rijn et al. 2003) or surfaced (Hashemi, Ghadampour, and Neill 2010) profile of a beach under different conditions. However, these 
authors have not taken into consideration the possible effect that marine vegetation can have on both waves and profile. Although other authors have taken it into account in other cases, such as planview evolution (Alvarez-Ellacuria et al. 2011). Therefore, the purpose of this study is to investigate the potential of an ANN to predict the cross-shore beach profile of sand beaches in areas with and without Posidonia oceanica. To this end, first, the variables that may influence the formation of the profile were studied and then different ANNs were generated (different input variables and number of hidden layers) and the architecture that best represents the cross-shore beach profiles in the study area was selected.

\section{Study area}

The study area is located in the western Mediterranean. Specifically, this work focuses on all sand beaches in the provinces of Valencia, Alicante and Murcia (Spain) (Figure 1). Valencia is a province located in the east of the Iberian Peninsula $\left(39^{\circ} 28^{\prime} 30.7^{\prime \prime} \mathrm{N}, 00^{\circ} 22^{\prime} 33^{\prime \prime} \mathrm{W}\right)$, within the Gulf of Valencia, which is the largest morphodynamic unit of the Spanish natural coastline. The 28 studied beaches have delta fans, dunes, lagoons, capes and ports in the coastal part and bars in the nearshore.

Meanwhile, the province of Alicante in the south of Valencia $\left(38^{\circ} 20^{\prime} 43^{\prime \prime} \mathrm{N}, 0^{\circ} 28^{\prime} 59^{\prime \prime} \mathrm{W}\right)$, is divided into two morphological zones: A zone formed by hills and riverside forests and mainly gravel beaches, comprising almost two thirds north (from the northern border of the province, until the Cape las Huertas). The southern third (from the Cape las Huertas to the southern border of the province) is made up of a large alluvial plain, and sandy beaches. In the province of Alicante, 38 beaches have been studied. 


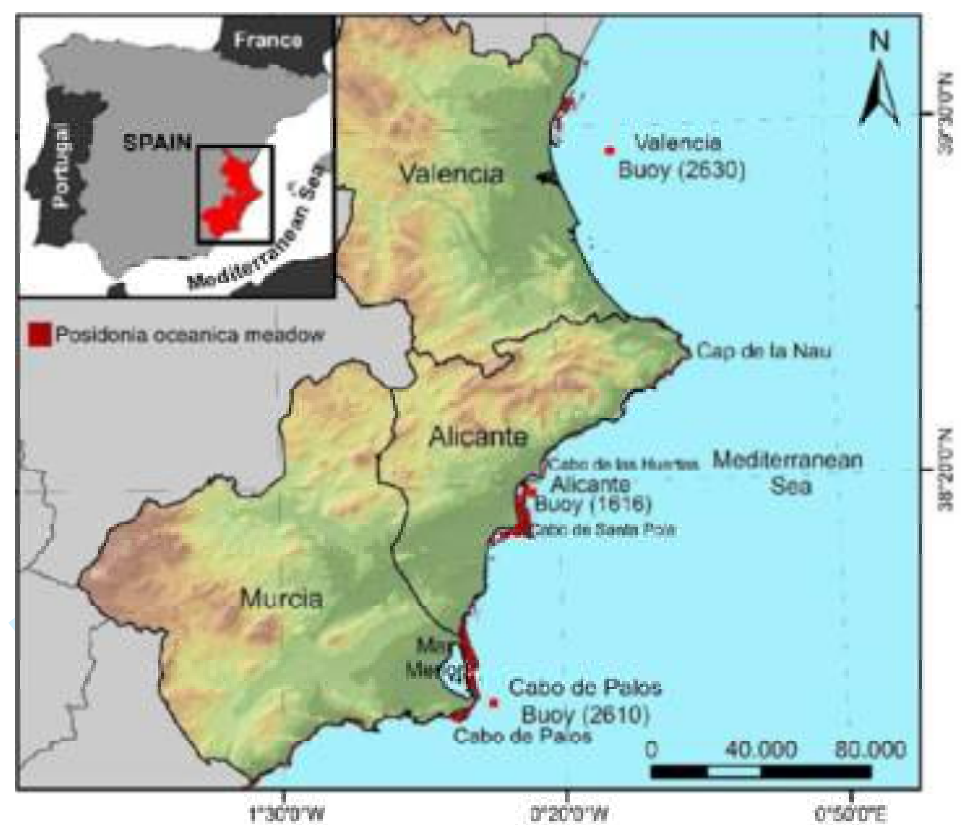

Figure 1. Location of the study area and the meadows of Posidonia oceanica. (no color is needed)

Murcia is located southeast of Spain $\left(37^{\circ} 59^{\prime} 10^{\prime \prime} \mathrm{N}, 1^{\circ} 07^{\prime} 49^{\prime \prime} \mathrm{W}\right)$, and the north-south divides into two parts, separated by a series of hills that form the South Mountain range parts. These two areas are: i) Field of Murcia south, is the northern part of the coastal plain of the Campo de Cartagena; and ii) Huerta de Murcia north, consist of a flood plain. On its coast, we can find systems of coastal dunes and beaches, wetlands and coastal marine influence. a period of $11.6 \mathrm{~s}$, while the most frequent waves in the area are from the $E$, with wave 109 heights of $2.8 \mathrm{~m}$ in deep waters and a period of $10.5 \mathrm{~s}$ (Ecolevante 2006). 
110

111

112

On the other hand, on the coastal front of Alicante and Murcia, the beaches are usually small and separated from each other, so in this case each of the beaches studied represents an independent physiographic unit. In the province of Alicante and up to Cabo de Palos (Murcia) the highest storms come from the E with wave heights of up to $4.5 \mathrm{~m}$ and periods of 10-12 s (Ecolevante 2006). According to López et al. (2016), the most frequent waves (ENE and E) produce North-South direction currents. In the southern part of the province of Murcia the predominant waves are those of the SE and SW with wave heights of up to $2.7 \mathrm{~m}$ and $4.2 \mathrm{~m}$, respectively (EcoMAG 2009).

On the other hand, astronomical tides range between $20 \mathrm{~cm}$ and $30 \mathrm{~cm}$ in the area of Valencia and Alicante (Ecolevante 2006) and between $20 \mathrm{~cm}$ and $40 \mathrm{~cm}$ in Murcia (EcoMAG 2009), and when they are affected by meteorological factors, the tides surges can be up to $75 \mathrm{~cm}$ in Alicante and Valencia, and $1 \mathrm{~m}$ in Murcia.

\section{Methodology}

In the developed methodology, first the variables that may be related to the formation of the profile (climate, sedimentology and biocenosis) are analysed. Then, the process for the generation of neural networks and the selection of the optimal architecture is described.

\subsection{Bathymetric profiles}

To obtain the cross-shore profiles, the bathymetry of the "Estudio ecocartográfico de las provincias de Valencia y Alicante (Ecolevante 2006)" and "Estudio ecocartográfico de las provincias de Granada, Almería y Murcia (EcoMAG 2009)" conducted by the General Directorate of Coasts were used. This bathymetry was obtained using two multibeam and a single beam probe from the coastline to the depth of $-40 \mathrm{~m}$. The simplified point cloud of the data returned by the echo sounder has a spatial resolution of $5 \times 5 \mathrm{~m}$ on the $\mathrm{XY}$ axis and \pm 
134

$0.15 \mathrm{~m}$ on the $\mathrm{Z}$ axis, from which a DTM (digital terrain model) was generated by TIN and, from the TIN, the bathymetric and cross-shore profiles were generated. From the shoreline to $-2 \mathrm{~m}$ the data were completed with RTK survey (EcoMAG 2009; Ecolevante 2006). No profile was discard because it was located in front of reefs or sand bars, but no profiles were taken on gravel beaches, the study was only carried out for sand beaches.

Given the resolution of the bathymetry and the length of the beaches, by using a GIS (Geographical Information System), profiles were obtained of the beaches (at least two), with a total of 418 profiles (140 in Valencia, 138 in Alicante and 140 in Murcia; Supplementary material 1). These profiles were divided into fifteen points $(x, y)$, of which $y_{i}$ will be the outputs of the ANNs. The 15 points were chosen so that the $x_{i}$ was constant for all profiles, and reach, at least, the depth of closure (DoC), calculated according to Birkemeier (1985). The $x_{i}$ values considered are: $x_{1}=10 m, x_{2}=20 m, x_{3}=40 m, x_{4}=60 m, x_{5}=80 m, x_{6}=$ $100 \mathrm{~m}, \mathrm{x}_{7}=125 \mathrm{~m}, \mathrm{x}_{8}=150 \mathrm{~m}, \mathrm{x}_{9}=175 \mathrm{~m}, \mathrm{x}_{10}=200 \mathrm{~m}, \mathrm{x}_{11}=250 \mathrm{~m}, \mathrm{x}_{12}=300 \mathrm{~m}, \mathrm{x}_{13}=350 \mathrm{~m}$, $\mathrm{x}_{14}=400 \mathrm{~m}$ and $\mathrm{x}_{15}=450 \mathrm{~m}$. Following the criteria established by López, Aragonés, Villacampa, and Compañ (2017), the points are closer at the landward edge of the profile and further apart $100 \mathrm{~m}$ from the shoreline, to represent adequately the concave shape of the profiles (Aragonés et al. 2016).

\subsection{Wave climate}

Wave data were obtained from directional buoys from the networks "REDEXT" and "REDCOST" of Public Agency Puertos del Estado (www.puertos.es). For Northern domain (from the northern boundary of the province of Valencia to Cape Nao), the Valencia 2630 buoy $\left(39^{\circ} 30^{\prime} 57.6^{\prime \prime} \mathrm{N}, 0^{\circ} 12^{\prime} 17.9^{\prime \prime} \mathrm{E}, 260 \mathrm{~m}\right.$ deep) was used. For beaches from Cabo Nao to Cape Santa Pola, the Alicante 1616 buoy $\left(38^{\circ} 15^{\prime} 0.0^{\prime \prime} \mathrm{N}, 0^{\circ} 24^{\prime} 35.9^{\prime \prime} \mathrm{W}, 52 \mathrm{~m}\right.$ deep), was used. And for southern domain, the Cabo de Palos 2610 buoy $\left(37^{\circ} 39^{\prime} 3.6^{\prime \prime} \mathrm{N}, 0^{\circ} 09^{\prime} 37.2^{\prime \prime} \mathrm{W}, 230 \mathrm{~m}\right.$ 
deep) was used. Since Alicante buoy is in intermediate water, data were carried to deep water using the function, $H_{0}=H_{R} \cdot K_{\alpha} / K_{R}$, given by the ROM_0.3-91 (1991), where $K_{\alpha}$ is the coefficient of directional distribution and $K_{R}$ is the coefficient of refraction-shoaling, $H_{0}$ is the wave height in deep water and $\mathrm{H}_{\mathrm{R}}$ the wave height at the buoy.

For the study, different wave heights, periods, directions, and probability of occurrence (p) were accounted for, to determine the most influential in the profile. The different wave heights, and their associated periods, occurrence probabilities and directions used are: waves of highest frequency (MF), waves of the highest energy (highest wave height, ME), and waves associated with the direction perpendicular to the coast (PC). All the data were obtained using the software AMEVA V1.4.3 (IHCantabria 2013), and are referred to as the wave height exceeded 12 hours a year $\left(H_{s, 12}\right)$.

Moreover, the wave height at breaking $\left(H_{b}\right)$ was obtained by two methods: i) using the methodology proposed by the Recommendation for Marine Works (ROM_0.3-91 1991), which considers refraction and shoaling, and ii) using the formulation proposed by Goda (2010).

\subsection{Sediment characteristics}

Sediment samples were obtained from a survey conducted by the University of Alicante in 2012 (Alicante), 2013 (Valencia) and 2014 (Murcia). For the 103 studied beaches, 453 samples were analysed ( 4 to 5 samples per beach evenly distributed along the shoreline). Samples were taken in the swash zone, and were saved in a bucket to be labelled. Sediment was collected by dragging on the bottom a plastic bag inserted in an oval metallic frame, giving a vertical penetration in the sediment of about $2-4 \mathrm{~cm}$. The weight of samples ranged from 200 to $500 \mathrm{~g}$. After being packed into bags the samples were transported in an icebox to the laboratory. 
182

183

184

185

186

187

For each sample, the median sediment size $\left(D_{50}\right)$, real sample density $(\rho m)$, the material density ( $\rho$ ) and the porosity ( $p$ ) were obtained following the UNE 103 101: 1995, the UNE 7050-2: 1997 and the UNE 103 100: 1995. Also the following scientific literature was taken into account: Syvitski (2007); Román-Sierra, Muñoz-perez, and Navarro-Pons (2013).For the characterization of the cross-shore profiles, the data obtained from the nearest sample to each profile were used.

\subsection{Posidonia oceanica}

In the provinces of Alicante and Murcia, there is an extensive presence of Posidonia oceanica meadows (Figure 1). This marine phanerogama plays an important role in the beach profile. Some of the most important effects are: i) Improvement of retention of suspended particles (Terrados and Duarte 2000; Gacia and Duarte 2001), ii) consolidates the sediment, acting as a reef profile, generating a profile more vertical than unprotected ones (Fonseca 1996; Muñoz-Perez and Medina 2010). That is why the profile slope will be studied from the shoreline to the beginning of the Posidonia meadow. iii) the friction of the plant leaves with water produces a reduction in the incident wave energy (Gambi et al. 1989; Gacia and Duarte 2001), so the energy reduction coefficient $K_{v}$ will be studied. And iv) Protection of the erosion of beaches by the accumulation of leaves on the coast (Boudouresque and de Grissac 1983). Although the protection role of seagrass banquettes should be reconsidered, since seagrass cast accumulations are continuously built up and destroyed and rarely persist before the arrival of new sea storms (Gómez-Pujol et al. 2013).

\subsubsection{Energy reduction coefficient $\left(K_{v}\right)$}

For obtaining energy reduction coefficient $\mathrm{K}_{\mathrm{v}}$, the function proposed by Mendez and Losada (2004) for variable depth (Eq. 1) was used, because all the meadows are on sloping bottoms.

$$
K_{v}=\frac{1}{1+\lambda x}
$$


206

207

208

209

210

211

212

Where $K_{V}$ is the reduction coefficient, $\lambda$ is a parameter related to the characteristics of the plant and swell (Eq. 2), and $\mathrm{x}$ is the distance along meadow ( $m$ ).

$\lambda=\frac{4}{9 * \pi} \cdot C_{D} \cdot b_{v} \cdot N \cdot H_{0} \cdot k \cdot \frac{\sinh ^{3}(k \cdot \delta \cdot h)+3 \cdot \sinh (k \cdot \delta \cdot h)}{(\sinh (2 \cdot k \cdot h)+2 \cdot k \cdot h) \cdot \sinh (k \cdot h)}$

where $b_{v}$ is the plant area per unit height of vegetation in the direction normal to speed, $N$ is the plant density $\left(\right.$ stems $/ \mathrm{m}^{2}$ ), $\delta$ is the relative plant height with respect to the water depth (h), $k$ is the wave number, and $C_{D}$ is the drag coefficient (Eq. 3).

$C_{D}=\alpha+\left(\frac{\beta}{R e}\right)^{\gamma}$

where $R e$ is the Reynolds number and $\alpha, \beta$ and $\gamma$ are empirical parameters proposed by Méndez, Losada, and Losada (1999); Cavallaro et al. (2011); Koftis and Prinos (2012); Maza, Lara, and Losada (2013) (Table 1). Because of the diversity of the proposed values, it was decided that $C_{D}$ be determined through values proposed by each of the authors and see which was better suited for the study area. The required data (plant density, stem height, leaf length, depth, and width of P. oceancia, which lies in front of each of the beaches) were obtained from EcoMAG (2009) and Ecolevante (2006).

In order to take into account only the energy reduction due to Posidonia oceanica meadows, those beaches with bare sandy bottom were assigned a value of $\mathrm{K}_{\mathrm{v}}=0$.

Table 1. Parameters $\alpha, \beta$ and $\gamma$, to calculate drag coefficient $\left(C_{D}\right)$, according to the literature

\begin{tabular}{lcccc}
\hline Studies & $\boldsymbol{\alpha}$ & $\boldsymbol{\beta}$ & $\mathbf{Y}$ & Range $\mathbf{R}_{\mathbf{e}}$ \\
\hline Méndez et al. (1999) & 0.4 & 4600 & 2.9 & $2300-20000$ \\
Cavallaro et al. (2011) & 0 & 2100 & 1.7 & $200-15500$ \\
Koftis and Prinos (2012) & 0.1 & 2100 & 1 & $1000-3200$ \\
Maza et al. (2013)_01 & 0.87 & 2200 & 0.88 & $4000-6000$ \\
Maza et al. (2013)_02 & 1.61 & 4600 & 1.9 & $2000-7000$ \\
\hline
\end{tabular}

3.4.2. Slope 
slope of the profiles located in Posidonia oceanica zones is larger than the profiles located in naked sandy bottoms (Figure 2). The mean slope of the profiles without Posidonia oceanica is $0.015 \pm 0.003$, while the slope of the profiles with Posidonia oceanica is $0.026 \pm 0.009$. In addition, it has been observed that in the analysed beaches the DoC estimated from the formulation proposed by Birkemeier (1985) is always within the meadow of Posidonia.

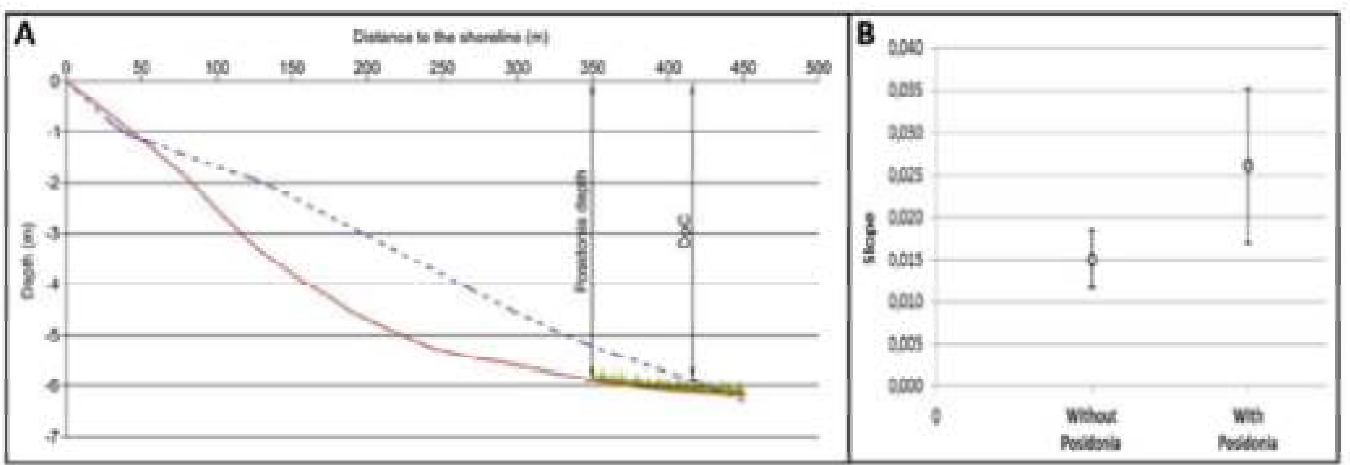

Figure 2. A) Comparison of profiles with and without the presence of Posidonia oceanica to two beaches with similar characteristics ( $D_{50}$ and incident wave energy). The straight line is on the Caseta de la Mare de Deu Beach (Alicante) and has Posidonia. The dashed line belongs to El Saler beach (Valencia), without the presence of Posidonia. B) Average value and standard deviation of the slope, on the beaches with and without seagrass. (no color is needed)

\subsection{Artificial neural networks modelling}

An artificial neural network system (ANNS) is a system made up of artificial neurons that emulates the concepts of the nervous system. An artificial neuron is an elemental processor so that from an input vector coming from the outside or from other neurons it provides a single response or output. In addition, the neurons will be organized in structural units called layers; several layers will constitute a neural network, and finally, a neural network (or set of them), along with the input and output interfaces, plus the necessary additional modules, will constitute the overall process system.

In the set of layers that constitute a neural network, three types are distinguished: i) Input layer. It consists of neurons that receive data or signals from the environment (where independent variables are introduced); ii) Hidden Layer(s). It is the one that does not have a 
direct connection with the environment (a number of neurons is selected in the layer, the allocation of weights is produced and the computational process is carried out); iii) Output layer. It is the layer whose neurons provide neuronal network response (where the results are shown).

For this work, the methodology described by López, Aragonés, Villacampa, and Compañ (2017) was followed. To obtain neural networks, MATLAB code-generated software/software (MathWorks, Inc., Natwick, MA) and the Neural Network Toolbox libraries were used. In which the backpropagation (BP) algorithm was applied together with the Levenber-Marquardt (LMA) algorithm, as it improves the calculation speed by using the second derivative approach method (Wang 2004). In order to avoid over-adjustment and obtain a good predictive model, the validation set is used to monitor the performance of the model during the training phase and to minimize over fitting, and 50 models were generated in each architecture selected in the hidden layer, i.e. 50 models were run independently, to avoid the effects caused by the automatic selection of the initial weights given to each neuron, as well as the selection of the profiles used for training or testing.

In order to determine the variables that would be used as input variables, in the input layer, the correlations between each of the analysed variables and each of the points of the profiles (outputs) were first studied using the SPSS statistical software.

The results show that the variables $D_{50}, H_{0}(P C), p(P C)$ and $T(P C)$ are the variables that best define the profile, which is consistent with the results obtained by López, Aragonés, Villacampa, and Compañ (2017). However, it can be seen that at the intermediate points of the profile $\left(125-250 \mathrm{~m}\right.$ ), the $\mathrm{K}_{\mathrm{v}}$ factor of Koftis (hereafter $\mathrm{K}_{\mathrm{v}}$ ) and the slope have an important influence. This is why three types of network models with different variables have been generated, one using the same variables as López, Aragonés, Villacampa, and Compañ 
272 (2017) and two more progressively adding the variables $K_{v}$ and slope, to see the influence of 273 these two variables on the results. The three types of generated networks have in the input 274 layer the following variables:

2) ANN2: $D_{50}, H_{0}(P C), T(P C), p(P C)$ and $K_{v}$

In each case, for the identification of ANN the input data were divided into three groups.

Thus, the training, validation and test groups have dimensions of $313(75 \%)$ profiles, 42 (10\%) profiles and $63(15 \%)$ profiles, respectively. Since the profiles used in each of the groups are randomly selected by the program, each model was run 50 times, to rule out the influence of the variability of the input data in each group (training, validation, testing). The outputs correspond to the 15 points that define the profiles $\left(y_{1}, y_{2}, \ldots y_{15}\right)$.

For network optimization, the number of neurons in the hidden layer ranged from 1 to 20 . The optimal ANN architecture was determined based on the Pearson's coefficient $\left(R^{2}\right)$ of training, validation and testing sets. Therefore, the criterion for selecting the optimal model was to obtain the maximum value of $R^{2}$ with the lowest dispersion of results in the 50 executions during test and training.

To determine the performance of the selected network model, three different criteria were used: absolute error (Eq. 4), mean absolute percentage error (MAPE, Eq. 5) and percentage relative error (Eq. 6). 
294

295

296

297

298

299

300

301

302

303

304

305

306

307

308

309

310

311

312

$$
\delta=\sqrt{\frac{\sum_{\mathrm{i}=1}^{\mathrm{n}}\left(\mathrm{r}_{\mathrm{i}}-o_{\mathrm{i}}\right)^{2}}{(\mathrm{n}-\mathrm{p}) \frac{1}{\mathrm{n}} \sum_{\mathrm{i}=1}^{\mathrm{n}}\left(\mathrm{r}_{i}\right)^{2}}}
$$

Where $r_{i}$ corresponds to the measured values, $o_{i}$ are the values obtained from the network, $n$ is the number of values and $p$ is the number of free parameters of expression.

Finally, the results obtained are compared with the model for the equilibrium transverse profile proposed by Dean (1977), since it is the most used by coastal engineers in coastal regeneration. In addition, it is also compared with the numerical model developed by Aragonés et al. (2017) to obtain the equilibrium profile in areas with Posidonia oceanica.

\section{Results}

First, the results of the study of the correlations between the different analysed variables and each of the points of the profile that are part of the output of the neural network are shown (Table 2). As can be seen, the correlation values are generally low in the points closer to the shoreline, although they are quite high in the endpoints. The variables that have greater relationship with all points are: $D_{50}, H_{0}(P C) T(P C)$ and $p(P C)$, with an average in absolute value of $0.645,0.550,0.549$ and 0.546 . Also highlight the slope $(\mathrm{m})$ and the coefficient $\mathrm{K}_{\mathrm{v}}$. Although, the correlation mean values are between 0.3 and 0.4 , correlations with intermediate points of the profile $(125-250 \mathrm{~m})$ are greater than 0.5 in all cases. The correlations indicate the linear relationships between two variables, but this does not mean that in non-linear models, such as ANN, the combination of variables which present the highest correlations obtain the best results. Therefore, it was decided to generate several neural networks with different input variables.

Figure 3 shows the $\mathrm{R}^{2}$ value obtained for each ANN (ANN1, ANN2 and ANN3) for training and test. As can be seen results at training and test are similar. Among the architectures, ANN [6-10-15] (inputs, neurons in hidden layer, outputs) was selected, since presents the highest 
317 value of the mean $R^{2}$ with the lowest dispersion $(0.907 \pm 0.019$ for test and $0.901 \pm 0.019$ for 318 training). Although, there are other architectures with high values of $R^{2}$ such as [6-16-15], 319 whose results are very similar $(0.897 \pm 0.022$ for test and $0.907 \pm 0.017$ for training), the 320 architecture [6-10-15] has lower number of neurons in the hidden layer.
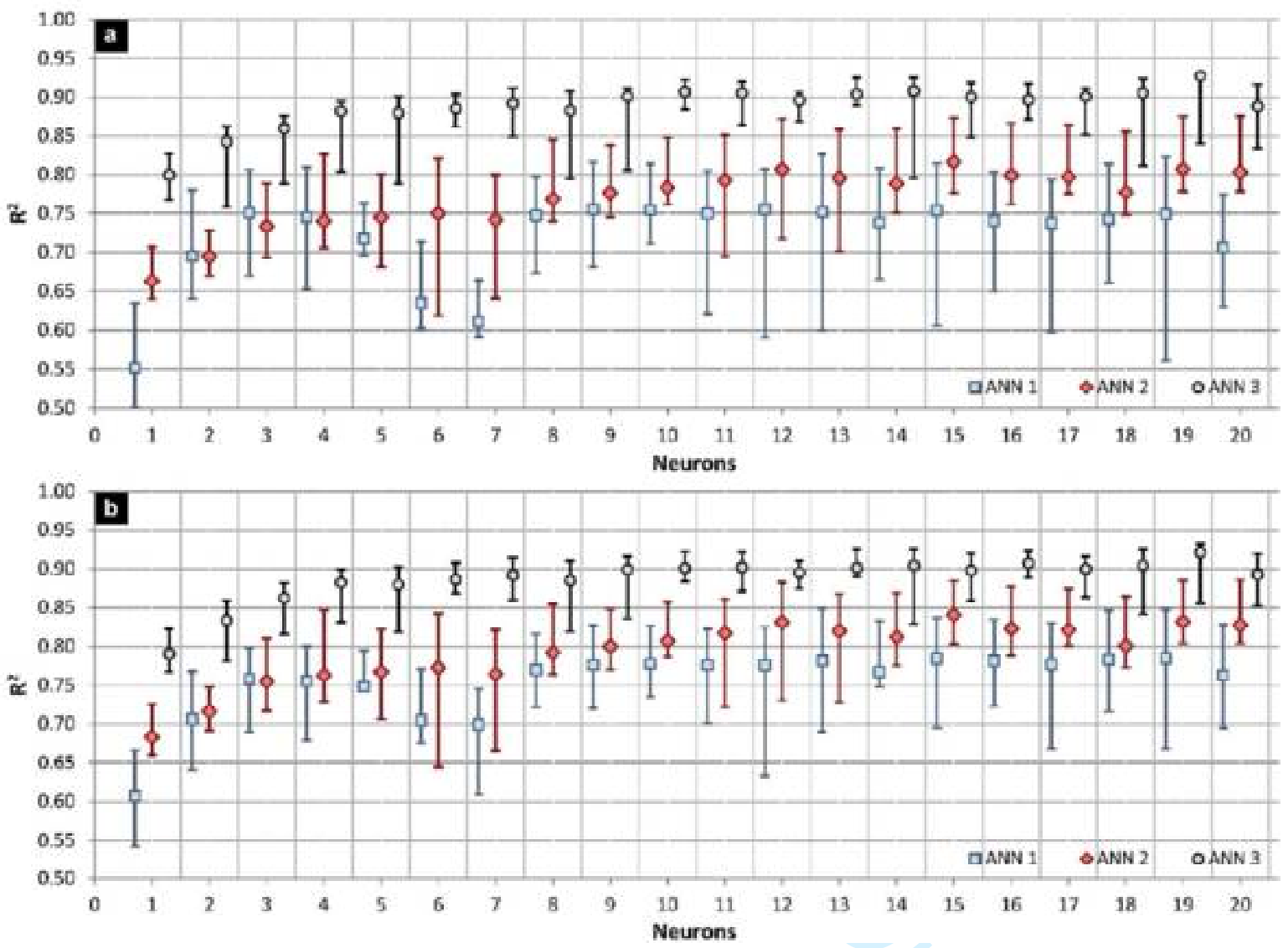

Figure 3. Mean values of $R^{2}$ for each of the analysed architectures in test (a) and training (b). (no color is needed) 


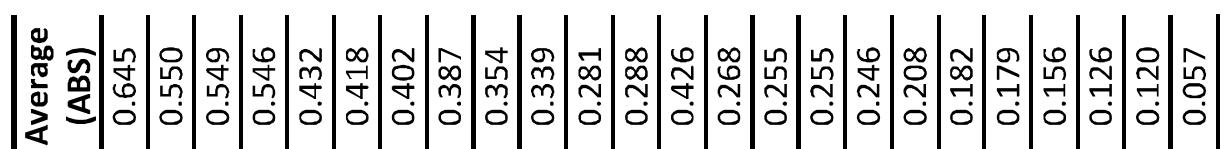

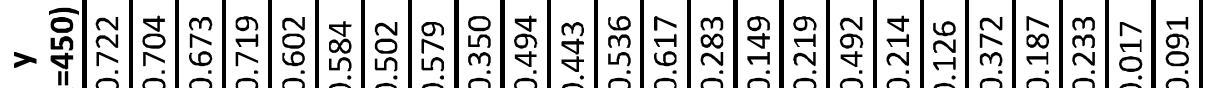

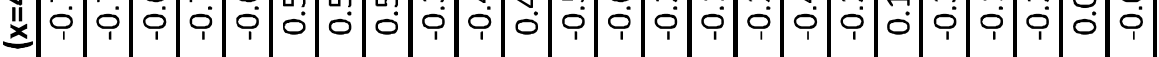

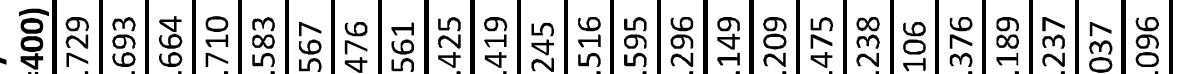

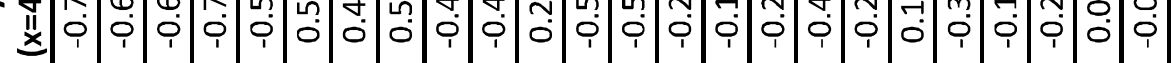

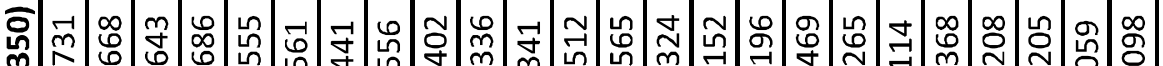

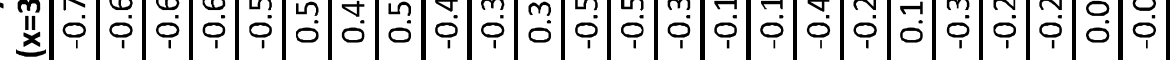

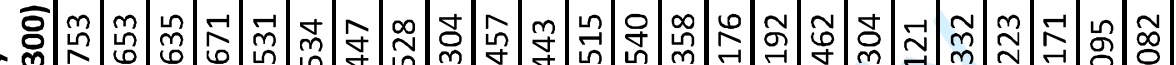

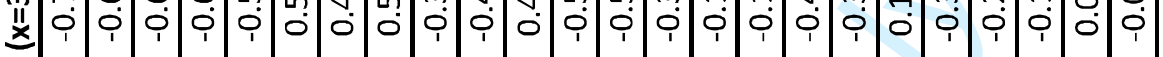

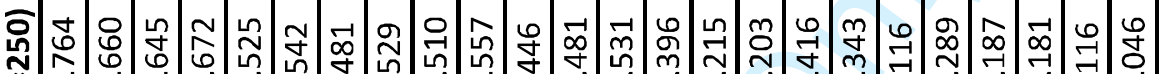
U

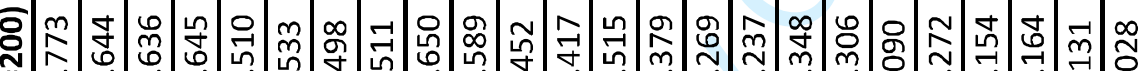

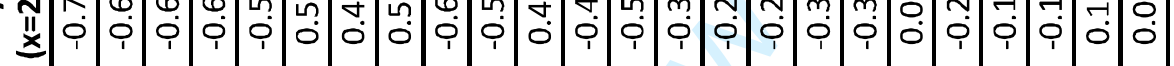

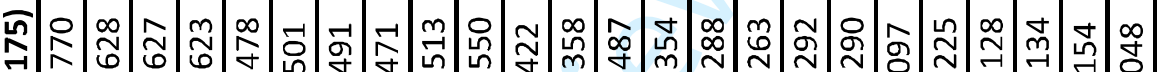

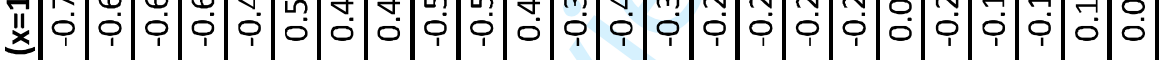

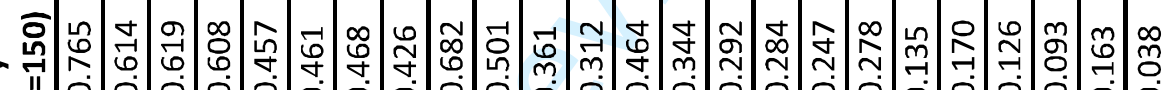

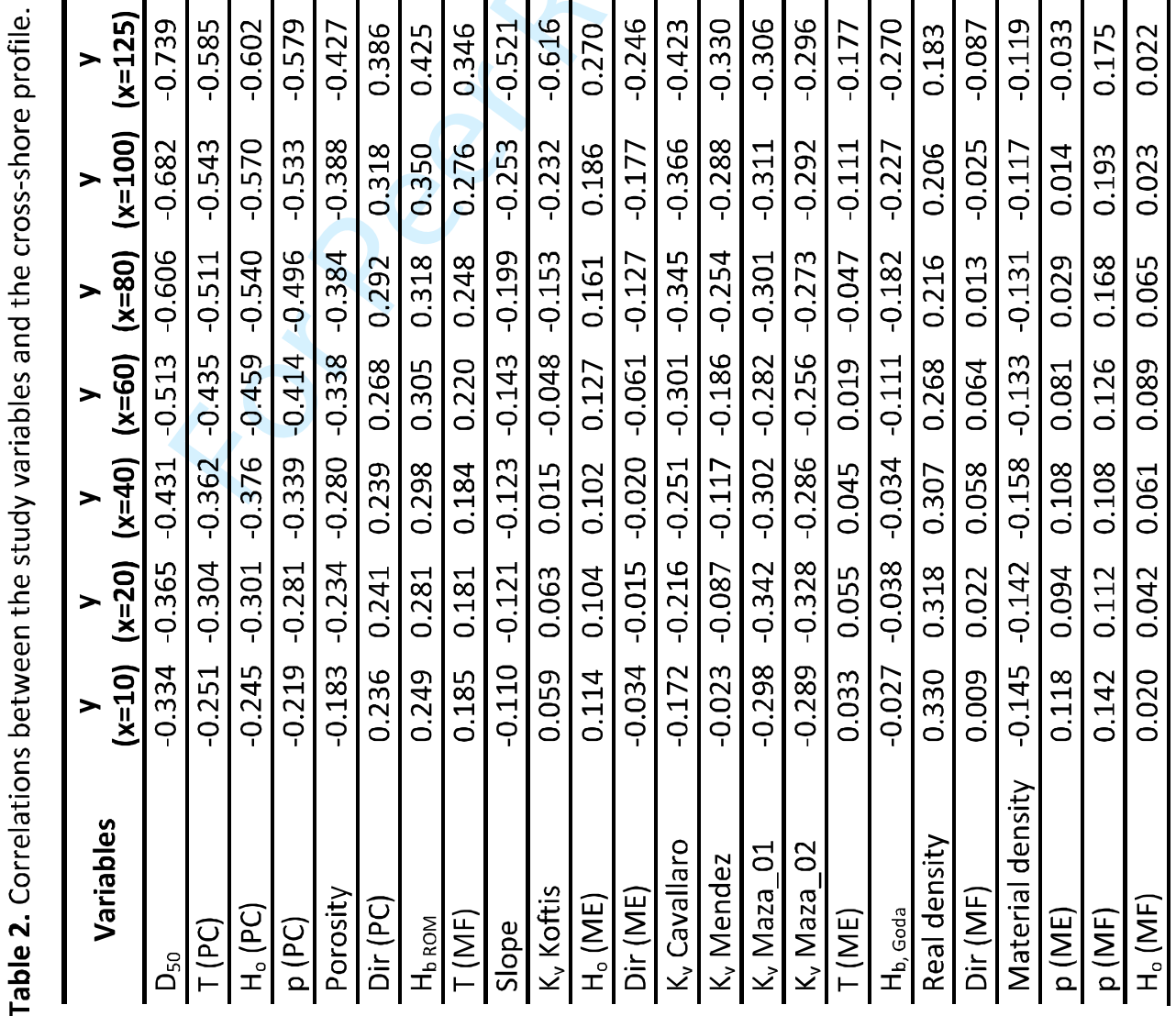

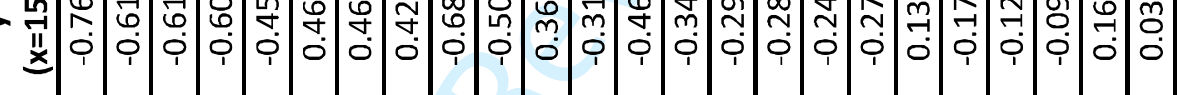


Figure 4 shows the absolute error for each of the profiles (sum in absolute value of the error in each point of the profile) and the mean value for the selected architecture [610-15] during training and test. The mean error is $0.22 \mathrm{~m}$ in training and $0.21 \mathrm{~m}$ in test, with a maximum of $0.74 \mathrm{~m}$ in the profile 183 in training (Alicante) and $0.52 \mathrm{~m}$ in the profile 405 in test (Murcia), and a minimum of $0.04 \mathrm{~m}$ in the profile 136 in training (Valencia) and $0.05 \mathrm{~m}$ in the profile 79 in test (Valencia). While in the Dean's and Aragonés' model the mean errors are $1.16 \mathrm{~m}$ and $0.49 \mathrm{~m}$, reaching a maximum of 7.02 $\mathrm{m}$ in the profile 353 and $3.85 \mathrm{~m}$ in the profile 352, respectively. In Figure 4c, this same error for each of the studied beaches is displayed (average of the sum in absolute value of the error in each point of the profiles belonging to each beach). In the case of Valencia, the mean error is $0.12 \mathrm{~m}$, the maximum error is $0.27 \mathrm{~m}$ in the beach $1 . \ln$ the provinces of Alicante and Murcia, the error increases until $0.28 \mathrm{~m}$. The maximum error is $6.30 \mathrm{~m}$ for Dean's formulation and $3.24 \mathrm{~m}$ for the Aragonés' model, producing on the beaches 82 and 81 , respectively.

Figure 5 shows the MAPE and percentage relative error $(\delta)$ for each beach (see supplementary material 2 for errors in each of the profiles). The MAPE and the percentage relative error for training and test data sets are very similar. The mean MAPE is 9.5 for training data set, while for test data set the mean is $8.1 \%$. The mean percentage relative error is $10.4 \%$ for training and $8.4 \%$ for test. By provinces the mean value of MAPE (for all profiles, training and tests data together) is $9.3 \%$, being $6.6 \%$ in the province of Valencia, $11.2 \%$ in Alicante and Murcia. Four beaches are remarkable for having values over $20 \%(32,33,65$ and 71$)$. While for the models of Dean and Aragonés, the MAPE is tripled, with mean values of $20.0 \%$ and $14.3 \%$ in Valencia, $34.8 \%$ and $25.4 \%$ in Alicante, and $53.6 \%$ and $39.6 \%$ in Murcia, respectively. As for the percentage relative error, the mean values are $4.4 \%, 7.6 \%$ and $6.9 \%$ in Valencia, 
351 Alicante and Murcia, respectively. If the data for each of the beaches (Figure 5) is 352 closely examined, it can be seen that only six beaches present values over $15 \%$ 353 (beaches 1, 2, 30, 35, 42 and 44). The percentage relative error for the Aragonés model 354 remains relatively low (28.5\% in Valencia, $26.2 \%$ in Alicante and $14.2 \%$ in Murcia), 355 however for Dean's function this error shows large values above $1500 \%$ in some 356 beaches (average in Valencia 510.5\%, in Alicante $259.3 \%$ and $57.8 \%$ in Murcia). 

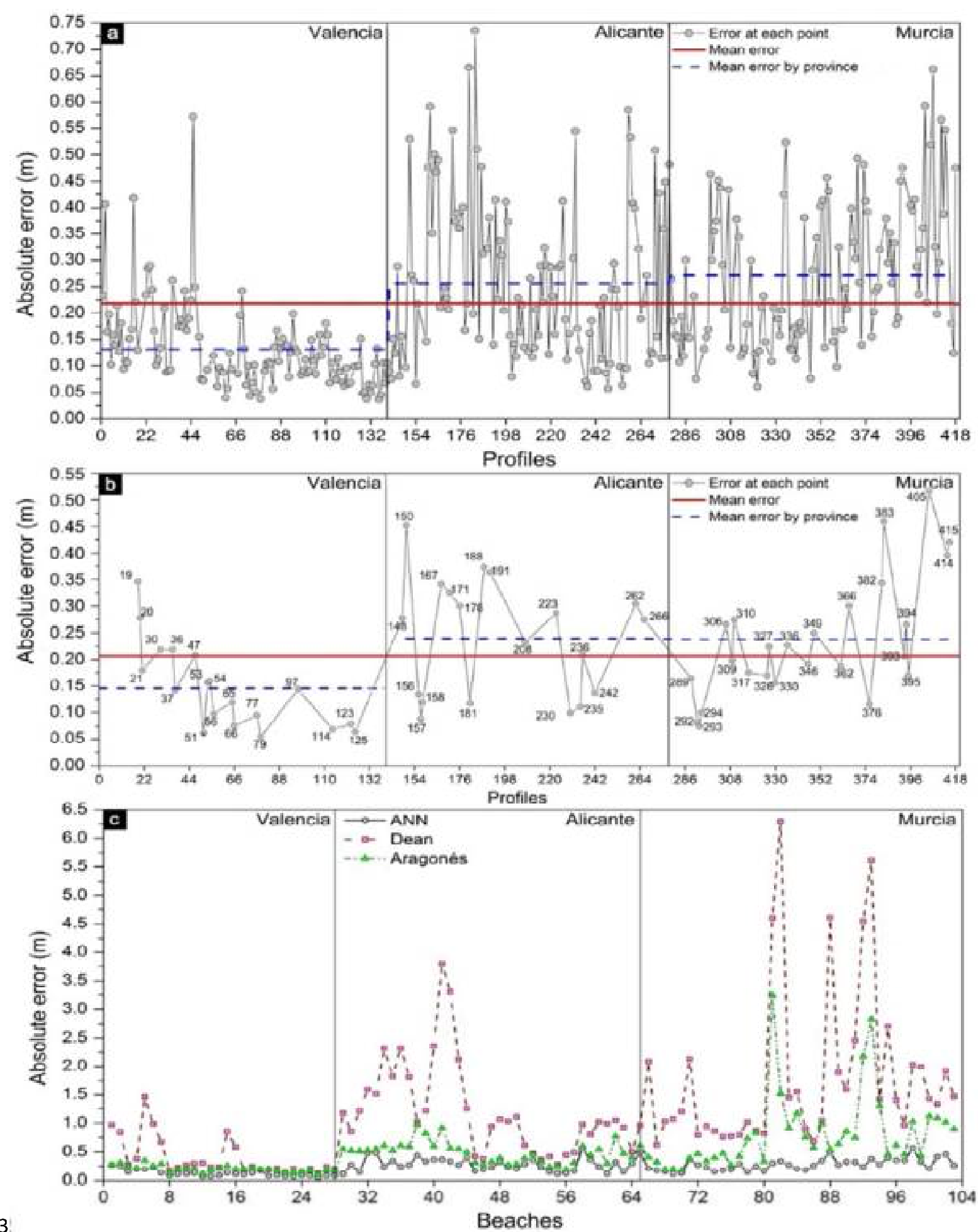

3

Figure 4. a) Absolute error ( $m$ ) of each profile of the ANN [6-10-15] during training and, b) 360 during test. c) Absolute error $(m)$ on each beach of the ANN [6-10-15] ANN, Dean's function and Aragonés' model. (no color is needed) 
361
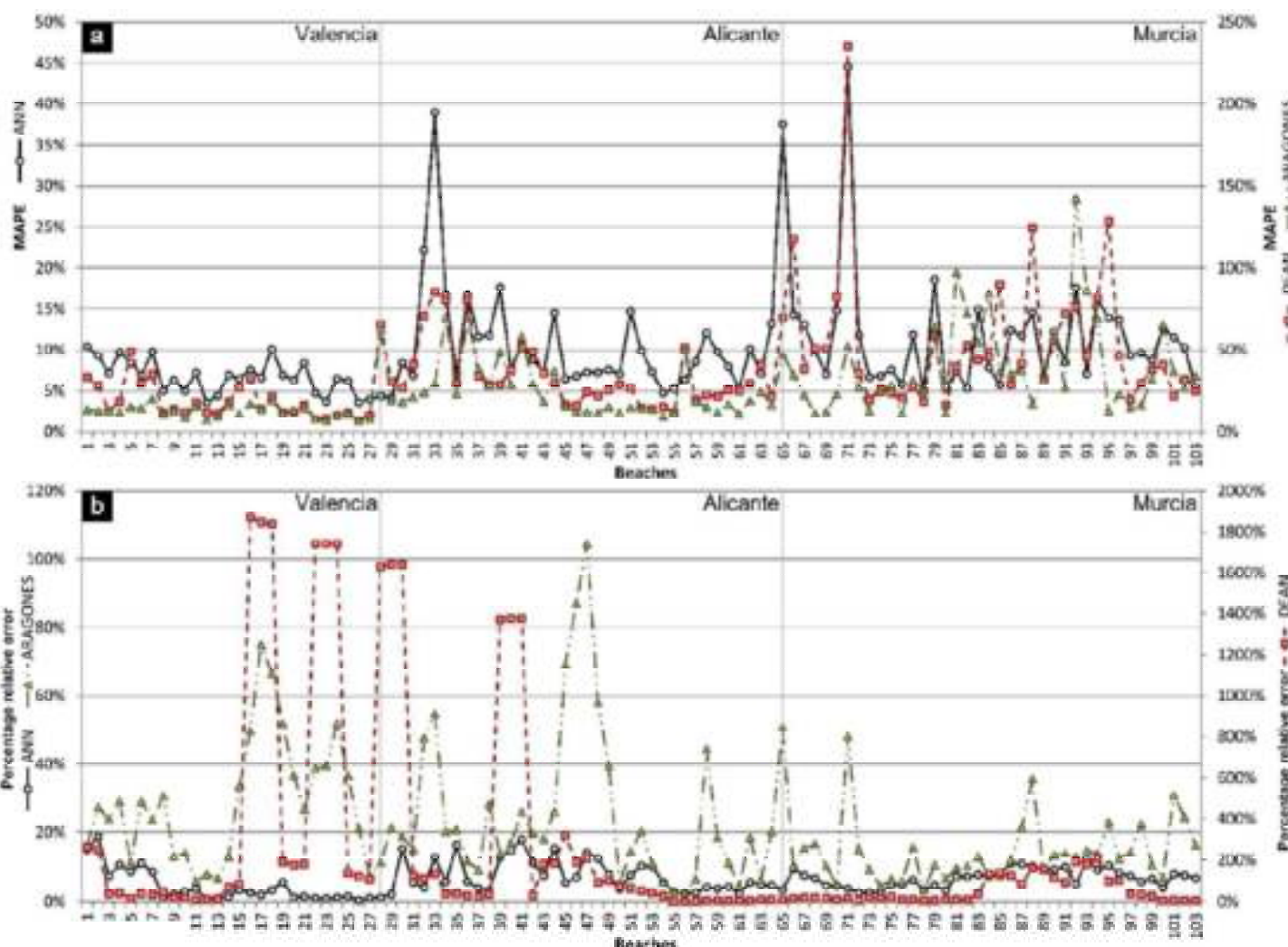

Figure 5. MAPE (a) and $\delta(\mathbf{b})$ for beach [6-10-15]. (no color is needed)

\section{Discussion}

A key factor in a beach nourishment is the cross-shore beach profile, since it is used for the design of different elements: i) volume of sand required in beach nourishment (Davison, Nicholls, and Leatherman 1992; Hinton and Nicholls 1998; Stive et al. 1992; Hallermeier 1981), ii) design of coastal defence structures (Jiménez and Sánchez-Arcilla 1993), or iii) the calculation of the sedimentary balance (Capiobianco et al. 2002). However, most of the models or formulations proposed so far do not take into account the presence of marine biocenosis acting consolidating the ground and increasing the profile slope (among others). As a result, large volume errors are often committed when calculating the volume of sand needed in beach nourishment, or locating the coastal defence elements. Therefore, models must be more and more precise, and to achieve this, it is necessary to take into account all those local factors that can affect 
375

376

377

378

the profile. The objective of this article is to check whether the inclusion of variables related to marine vegetation (energy reduction coefficient or slope) improve the results obtained by López, Aragonés, Villacampa, and Compañ (2017) when modelling the transverse beach profile.

First, an analysis of linear correlations shows (Table 2) that the factors most correlated with the cross-shore profile are those related to the waves perpendicular to the coast, namely, the period, the wave height and the frequency $(R=0.550,0.549$ and 0.546 , respectively). Regarding sedimentology, most formulations concerning beach profile are related to the median sediment size $\left(D_{50}\right)$ (Kriebel, Kraus, and Larson 1991; Vellinga 1984; Dean 1991), which is also justified in this study, in which $D_{50}$ is the one with the greatest correlation among the sedimentological parameters studied $(R=0.645)$. Finally, among the variables related with Posidonia oceanica, the slope and the coefficient $K_{v}$ obtained using data from Ecolevante (2006) and the parameters proposed by Koftis and Prinos (2012), is the one that has a greater relation to the profile, which agrees with the result obtained by Aragonés et al. (2017). Although they do not show large correlations with the profile, if look at each of the studied points, it can be seen that for the intermediate points $(125<x<250 \mathrm{~m})$ the correlations are greater than 0.5 . Therefore, it was decided to generate 60 neural networks (using different input variables and numbers of neurons in the hidden layer), in order to determine the individual influence of each of the variables, and choose the combination that gives best results.

The results of $\mathrm{R}^{2}$ (Figure 3 ) confirm the importance of Posidonia oceanica in the beach profile, being the architecture [6-10-15] which offers the best results $\left(R^{2}=0.907 \pm 0.019\right.$ for test and $\mathrm{R}^{2}=0.901 \pm 0.019$ for training), with results $7.3 \%$ better than ANN 1 (López, 
399

400

401

402

403

404

405

406

407

408

409

410

411

412

Aragonés, Villacampa, and Compañ (2017) model) which does not present any variable related to Posidonia, and $5.3 \%$ better than ANN 2, which includes only the coefficient $K_{v}$. Therefore, if this model were to be extrapolated to other study areas with the same characteristics, it would only be necessary to check the optimal number of neurons in the hidden layer to obtain the best results. However, it would not be necessary to check the input variables, as the results are much better when using slope and $\mathrm{K}_{\mathrm{v}}$ coefficient.

On the other hand, for evaluating the performance of the model, various statistical parameters were studied (Eq. 4, 5 and 6). By analysing these parameters, it was observed that the neural network improves the results compared to actual models (Dean and Aragonés). Thus, it was observed that the mean absolute error of the ANN (for all profiles, training and test data together) is $81.2 \%$ and $55.5 \%$ lower than Dean (0.22 $\mathrm{m}$ vs $1.16 \mathrm{~m}$ ) and Aragonés (0.22 m vs. $0.49 \mathrm{~m}$ ) models, respectively. The MAPE and the percentage relative error also exhibit an improvement over the numerical model of Aragonés; these errors were $64.0 \%$ and $71.3 \%$ lower. By analysing in detail the errors, it could be seen that the greatest errors occur mainly on the beaches 30 , $33,42,65,81$ and 102 . After the study of the inputs used in the profiles of these beaches (sediment, slope, morphology of the Posidonia meadow, etc.) no anomalous value was observed or that stood out with respect to the average of values used in the rest of the profiles (Table 3). However, these beaches presented the following singularities: i) Beaches with important nourishments (Figure 6a and 6c), therefore, perhaps the profile has not yet stabilized. ii) Beaches with rock reefs or islets in front of their coasts so the bathymetry is considerably altered, and therefore also the profiles are (Figure $6 b$ and $6 d$ ). These kinds of profiles represent only $5.5 \%(23 / 418)$ of the studied profiles, so the network is not able to learn effectively their singularities. In 
order to correct this problem, there are two options: a) remove these profiles from the ANN, and b) increase the sample size of data by Monte-Carlo simulations or by perturbing the input by say $5 / 10 \%$ or similar, however given the extent of the work this is left for future work. Nevertheless, the results obtained by the ANN in this area are lower than both Dean's formulation (72.7\% absolute error, $65.4 \%$ MAPE and $88.3 \%$ percentage relative error) and Aragonés model (36.9\% absolute error, 30.0\% MAPE and $82.5 \%$ percentage relative error) (Figure 5). The improvement in the accuracy of the profile results in a smaller volume error when calculating the amount of sand needed in beach nourishment, and therefore a lower economic cost, about $5.3-9.8$ $€ / \mathrm{m}$ of beach (assuming a cost of $11.5 € / \mathrm{m}^{3}$ (López, Aragonés, Villacampa, and Compañ 2017)). This cost savings certainly compensate the largest computational cost of the ANN versus the simplicity of the numerical models and the formulations.

Table 3. Average value and standard deviation of each of the variables studied and of the beaches with the greatest errors $(30,33,42,65,81$ and 102$)$.

\begin{tabular}{|c|c|c|c|c|c|c|}
\hline & $\mathrm{D}_{50}$ & $\mathrm{H}_{\circ}(\mathrm{PC})$ & $\mathrm{T}(\mathrm{PC})$ & $\mathrm{p}(\mathrm{PC})$ & $\mathrm{Kv}$ & Slope \\
\hline Average & $\mathbf{0 . 3 2 6 \pm 0 . 2 7 2}$ & $\mathbf{3 . 0 1} \pm \mathbf{0 . 8 8}$ & $\mathbf{1 1 . 0} \pm \mathbf{1 . 9}$ & $\mathbf{0 . 2 5 5 9 \pm 0 . 1 4 0 0}$ & $\mathbf{0 . 8 1 9 \pm 0 . 2 2 6}$ & $\mathbf{0 . 0 1 7 \pm 0 . 0 1 0}$ \\
\hline 30 & 0.338 & 1.90 & 8.3 & 0.1977 & 0.584 & 0.019 \\
\hline 33 & 0.240 & 2.13 & 12.3 & 0.2200 & 0.616 & 0.008 \\
\hline 42 & 0.242 & 1.99 & 8.7 & 0.2326 & 0.974 & 0.025 \\
\hline 65 & 0.259 & 3.00 & 10.0 & 0.3095 & 0.409 & 0.013 \\
\hline 81 & 0.313 & 2.41 & 12.5 & 0.1782 & 1.000 & 0.029 \\
\hline 102 & 0.315 & 2.40 & 10 & 0.2197 & 0.844 & 0.030 \\
\hline
\end{tabular}

Finally, the ANN developed here is not over-adjusted because, as can be seen from the results, the errors made during the training are very similar to those of the test. In addition, if the relationship between the number of data for training and the number of network parameters is analysed, a value of 52.2 is obtained that is much higher than the 5-20 value suggested in the literature to avoid overlearning (Hair et al. 2004). Furthermore, this ANN is based on the definition of the cross-shore beach profile in 
fifteen points separate so that its characteristics are defined generally. However, given the good results provided by the network, if the profile was very irregular it could increase the number of points that define the profile to improve the accuracy, although this would increase the computation time, provided that the areas where the model is applied have the same characteristics as the area studied here. If the new area of application presents different characteristics, such as tides, it should be checked whether the model is valid or whether it would be improved by adding the new variable (tide).

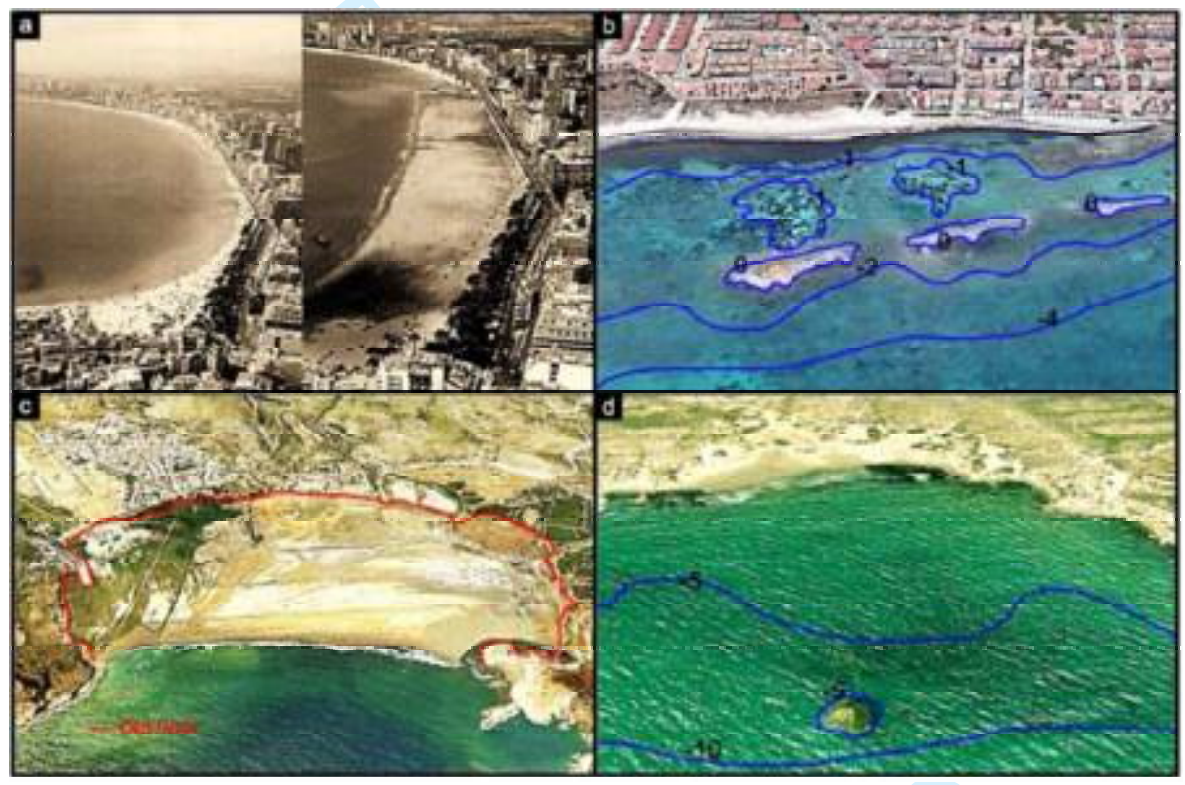

Figure 6. a) Poniente beach before and during the 1991 nourishment. b) Mojón beach with rock reefs. c) Portman beach with fillings from mining. d) Higuericas beach. (no color is needed)

\section{Conclusions}

For modelling the cross-shore profile of sand beaches with presence of Posidonia oceanica, different artificial neural networks were considered, with different input variables and different number of neurons in the hidden layer. The criterion for selection of the best model was getting the highest $R^{2}$ with the smallest dispersion of results in the 50 executions carried out for each model. Thus, it was found that the 
463

network [6-10-15] offered the best results (for test $R^{2}=0.907 \pm 0.019$ and for training $\left.R^{2}=0.901 \pm 0.019\right)$, where the input variables were formed by $D_{50}, H_{\circ}(P C), T(P C), p$ $(P C)$, slope $(m)$ and $K_{v}$ Koftis.

From results it was observed that the mean absolute error committed by the ANN during test was $0.21 \mathrm{~m}$ (0.22 $\mathrm{m}$ for training) while the Dean formulation and the Aragonés model amounted to $1.16 \mathrm{~m}$ and $0.49 \mathrm{~m}$, respectively. Also the MAPE and relative error rate values (for training $9.5 \%$ and $10.4 \%$ and for test $8.1 \%$ and $8.4 \%$, respectively) are much lower in the network compared to the Dean formulation (65.4\% and $88.3 \%$, respectively) and Aragonés model (30.0\% and $82.5 \%$, respectively). In addition, the network offered better results in beaches with very particular singularities (large non-stabilized anthropic fills and points that alter the bathymetry as rock reefs or islets), although errors were high because these beaches only represent the $5.5 \%$ of the studied profiles and therefore the learning of these profiles by the network was complex. To improve the results, a greater number of profiles with similar characteristics or eliminate these singular beaches from the model would be necessary.

\section{Acknowledgements}

The authors want to thanks the Jefatura Provincial de Costas de Alicante and Organismo Público Puertos del Estado for the information provided has enabled this study.

This research has been partially funded by Universidad de Alicante through the project "Estudio sobre el perfil de equilibrio y la profundidad de cierre en playas de arena" (GRE15-02).

\section{References}


Alvarez-Ellacuria, A, A Orfila, L Gómez-Pujol, G Simarro, and N Obregon. 2011. "Decoupling spatial and temporal patterns in short-term beach shoreline response to wave climate." Geomorphology no. 128 (3-4):199-208.

Allen, James R. 1981. "Beach erosion as a function of variations in the sediment budget, Sandy Hook, New Jersey, U.S.A." Earth Surface Processes and Landforms no. 6 (2):139-150. doi: 10.1002/esp.3290060207.

Aragonés, L., I. López, Y. Villacampa, and F. J. Navarro-González. 2017. "Using the presence of seagrass Posidonia oceanica to model the equilibrium profile parameter A of sandy beaches in Spain." Journal of Coastal Research no. 33 (3):642-652.

Aragonés, L., J. C. Serra, Y. Villacampa, J. M. Saval, and H. Tinoco. 2016. "New methodology for describing the equilibrium beach profile applied to the Valencia's beaches." Geomorphology no. 259:1-11. doi: http://dx.doi.org/10.1016/j.geomorph.2015.06.049.

Bernabeu, A. M., R. Medina, and C. Vidal. 2003. "Wave reflection on natural beaches: an equilibrium beach profile model." Estuarine, Coastal and Shelf Science no. 57 (4):577585. doi: http://dx.doi.org/10.1016/S0272-7714(02)00393-1.

Birkemeier, William A. 1985. "Field data on seaward limit of profile change." Journal of waterway, port, coastal, and ocean engineering no. 111 (3):598-602.

Boon, J. D., and M. O. Green. 1988. Caribbean beachface slopes and beach equilibrium profiles. Paper read at 21st Conference on Coastal Engineering, at Torremolinos, Spain.

Boudouresque, CF, and A Jeudy de Grissac. 1983. "L'herbier à Posidonia oceanica en Méditerranée: les interactions entre la plante et le sédiment." Journal de recherche océanographique no. 8 (2-3):99-122.

Boudouresque, CF, A Meinesz, M Ledoyer, and $\mathrm{P}$ Vitiello. 1994. Les herbiers à phanérogames marines, Les biocénoses marines et littorales de Méditerranée, synthèse, menaces et perspectives.

Bruun, P. 1954. Coast Erosion and the Development of Beach Profiles. In Vicksburg: Beach Erosion Board Technical Memorandum: U.S. Army Engineer Waterway.

Capiobianco, M., H. Hanson, M. Larson, H. Steetzel, M. J. F. Stive, Y. Chatelus, and T. Karambas. 2002. "Nourishment design and evaluation: Applicability of model concepts." Coastal Engineering no. 47 ((2)):113-135.

Cavallaro, Luca, Carlo Lo Re, Giovanni Paratore, Antonino Viviano, and Enrico Foti. 2011. Response of Posidonia oceanica to wave motion in shallow-waters-preliminary experimental results. Paper read at 32nd Conference on Coastal Engineering, at Shanghai, China.

Chen, Jia-Lin, Tian-Jian Hsu, Fengyan Shi, Britt Raubenheimer, and Steve Elgar. 2015. "Hydrodynamic and sediment transport modeling of New River Inlet (NC) under the interaction of tides and waves." Journal of Geophysical Research: Oceans no. 120 (6):4028-4047. doi: 10.1002/2014jc010425.

Davison, A.T., R.J. Nicholls, and S.P. Leatherman. 1992. "Beach nourishment as a coastal management tool: An annotated bibliography on developments associated with the artificial nourishment of beaches." Journal Coastal Research no. 8:984-1022.

Dean, R. G. 1977. Equilibrium Beach Profiles: U.S. Atlantic and Gulf Coasts. Department of Civil Engineering. In Ocean Engineering Technical Report. Newark, Delaware.: University of Delaware.

Dean, R.G. 1991. "Equilibrium beach profiles: characteristics and applications." Journal of Coastal Research no. 7 (1):53-84.

Demirci, Mustafa, Fatih Üneş, and M. Sami Aköz. 2015. "Prediction of cross-shore sandbar volumes using neural network approach." Journal of Marine Science and Technology no. 20 (1):171-179. doi: 10.1007/s00773-014-0279-9.

Ecolevante. 2006. Estudio ecocartográfico del litoral de las provincias de Alicante y Valencia: Dirección General de Costas, Ministerio de Medio Ambiente, Spain, [Available online: http://www.mapama.gob.es/es/costas/temas/proteccioncosta/ecocartografias/ecocartografia-alicante.aspx]. 
EcoMAG. 2009. Estudio ecocartográfico de las provincias de Granada, Almería y Murcia.: Dirección General de Costas, Ministerio de Medio Ambiente, Spain [Available online: http://www.mapama.gob.es/es/costas/temas/proteccioncosta/ecocartografias/ecocartografia-murcia.aspx].

Fonseca, MARK S. 1996. "The role of seagrasses in nearshore sedimentary processes: a review." Estuarine Shores: Hydrological, Geomorphological and Ecological Interactions. Blackwell, Boston, MA:261-286.

Gacia, E., T. C. Granata, and C. M. Duarte. 1999. "An approach to the measurement of particle flux and sediment retention within seagrass (Posidonia oceanica) meadows." Aquatic Botany no. 65:255-268.

Gacia, Esperança, and Carlos M Duarte. 2001. "Sediment Retention by a Mediterranean Posidonia oceanica Meadow: The Balance between Deposition and Resuspension." Estuarine, Coastal and Shelf Science no. 52 (4):505-514.

Gambi, MC, MC Buia, E Casola, and M Scardi. 1989. Estimates of water movement in Posidonia oceanica beds: a first approach. Paper read at International workshop on Posidonia beds.

Ghorbani, Mohammad Ali, Rahman Khatibi, Ali Aytek, Oleg Makarynskyy, and Jalal Shiri. 2010. "Sea water level forecasting using genetic programming and comparing the performance with artificial neural networks." Computers \& Geosciences no. 36 (5):620627.

Goda, Yoshimi. 2010. "Reanalysis of regular and random breaking waves statistics." Coastal Engineering Journal no. 52 (01):71-106. doi: 10.1142/s0578563410002129.

Gómez-Pujol, Lluís, Alejandro Orfila, Amaya Álvarez-Ellacuría, Jorge Terrados, and Joaquin Tintoré. 2013. "Posidonia oceanica beach-cast litter in Mediterranean beaches: a coastal videomonitoring study." Journal of Coastal Research no. 65 (sp2):1768-1773.

Hair, Joseph F, William C Black, Barry J Babin, Rolph E Anderson, and Ronald L Tatham. 2004. Multivariate data analysis. Vol. 5: Prentice hall Upper Saddle River, NJ.

Hallermeier, R. J. 1981. "A profile zonation for seasonal sand beaches from wave climate." Coastal Engineering no. 4 (3):253-277.

Hashemi, M. R., Z. Ghadampour, and S. P. Neill. 2010. "Using an artificial neural network to model seasonal changes in beach profiles." Ocean Engineering no. 37 (14-15):13451356. doi: http://dx.doi.org/10.1016/j.oceaneng.2010.07.004.

Hinton, C., and R. J. Nicholls. 1998. "Spatial and temporal behaviour of depth of closure along the Holland coast." Proceedings of 26th International Conference on Coastal Engineering, ASCE:2913-2925.

Huang, Wenrui, Catherine Murray, Nicholas Kraus, and Julie Rosati. 2003. "Development of a regional neural network for coastal water level predictions." Ocean Engineering no. 30 (17):2275-2295.

Iglesias, G, I López, A Castro, and R Carballo. 2009. "Neural network modelling of planform geometry of headland-bay beaches." Geomorphology no. 103 (4):577-587.

Análisis Matemático y Estadístico de Variables Medioambientales (AMEVA), Cantabria, Spain. Available online: http://ihameva.ihcantabria.com/.

Jiménez, J. A., and A. Sánchez-Arcilla. 1993. "Medium-term coastal response at the Ebro Delta, Spain." Marine Geology no. 114(1):105-118.

Keshtpoor, Mohammad, Jack A. Puleo, Fengyan Shi, and Nicholas R. DiCosmo. 2015. "Numerical Simulation of Nearshore Hydrodynamics and Sediment Transport Downdrift of a Tidal Inlet." Journal of Waterway, Port, Coastal, and Ocean Engineering no. 141 (2):04014035. doi: doi:10.1061/(ASCE)WW.1943-5460.0000273.

Koftis, Theoharris, and Panayotis Prinos. 2012. "Estimation of wave attenuation over Posidonia Oceanica." Mitteilungen des Lehrstuhls und Instituts für Wasserbau und Wasserwirtschaft der Rheinisch-Westfälischen Technischen Hochschule Aachen no. 165.

Kriebel, David L, Nicholas C Kraus, and Magnus Larson. 1991. Engineering methods for predicting beach profile response. Paper read at Coastal Sediments (1991). 
Larson, M., and N Kraus. 1995. "Prediction of cross-shore sediment transport at different spatial and temporal scales." Marine Geology no. 126 (1):111-127.

López, Isabel, L. Aragonés, Y. Villacampa, and P. Compañ. 2017. "Artificial neural network modeling of cross-shore profile on sand beaches: The coast of the province of Valencia (Spain)." Marine Georesources \& Geotechnology:1-11. doi: 10.1080/1064119x.2017.1385666.

López, Isabel, Luis Aragonés, Yolanda Villacampa, and José C. Serra. 2017. "Neural network for determining the characteristic points of the bars." Ocean Engineering no. 136:141-151. doi: https://doi.org/10.1016/j.oceaneng.2017.03.033.

López, M., I. López, L. Aragonés, J. C. Serra, and V. Esteban. 2016. "The erosion on the east coast of Spain: Wear of particles, mineral composition, carbonates and Posidonia oceanica." Science of The Total Environment no. 572:487-497. doi: https://doi.org/10.1016/j.scitotenv.2016.08.076.

Manca, E, I Cáceres, JM Alsina, Vicky Stratigaki, I Townend, and CL Amos. 2012. "Wave energy and wave-induced flow reduction by full-scale model Posidonia oceanica seagrass." Continental Shelf Research no. 50:100-116.

Masselink, Gerhard, and Ling Li. 2001. "The role of swash infiltration in determining the beachface gradient: a numerical study." Marine Geology no. 176 (1-4):139-156. doi: http://dx.doi.org/10.1016/S0025-3227(01)00161-X.

Maza, Maria, Javier L. Lara, and Inigo J. Losada. 2013. "A coupled model of submerged vegetation under oscillatory flow using Navier-Stokes equations." Coastal Engineering no. 80 (0):16-34. doi: http://dx.doi.org/10.1016/j.coastaleng.2013.04.009.

Medina, J. R., Joaquín Tintore, and Carlos M Duarte. 2001. "Praderas de Posidonia oceánica y la regeneración de playas." Revista de Obras Públicas no. 3.409:31-43.

Mendez, Fernando J, and Inigo J Losada. 2004. "An empirical model to estimate the propagation of random breaking and nonbreaking waves over vegetation fields." Coastal Engineering no. 51 (2):103-118.

Méndez, Fernando J., Iñigo J. Losada, and Miguel A. Losada. 1999. "Hydrodynamics induced by wind waves in a vegetation field." Journal of Geophysical Research: Oceans no. 104 (C8):18383-18396. doi: 10.1029/1999jc900119.

Muñoz-Perez, J. J., and R. Medina. 2010. "Comparison of long-, medium- and short-term variations of beach profiles with and without submerged geological control." Coastal $\begin{array}{llll}\text { Engineering no. } & 57 & (3): 241-251 . & \end{array}$ http://dx.doi.org/10.1016/j.coastaleng.2009.09.011.

Neill, Simon P., Alan J. Elliott, and Mohammad R. Hashemi. 2008. "A model of inter-annual variability in beach levels." Continental Shelf Research no. 28 (14):1769-1781. doi: http://dx.doi.org/10.1016/j.csr.2008.04.004.

Pasqualini, V., C. Pergent-Martini, P. Clabaut, and G. Pergent. 1998. "Mapping ofPosidonia oceanicausing Aerial Photographs and Side Scan Sonar: Application off the Island of Corsica (France)." Estuarine, Coastal and Shelf Science no. 47 (3):359-367. doi: https://doi.org/10.1006/ecss.1998.0361.

Pergent-Martini, C., V. Leoni, V. Pasqualini, G. D. Ardizzone, E. Balestri, R. Bedini, A. Belluscio, T. Belsher, J. A. Borg, C. F. Boudouresque, S. Boumaza, J. M. Bouquegneau, M. C. Buia, S. Calvo, J. Cebrian, E. Charbonnel, Cossu A. Cinelli F, Di Maida G., B. Dural, P. Francour, S. Gobert, G. Lepoint, A. Meinesz, H. Molenaar, H. M. Mansour, P. Panayotidis, A. Peirano, G. Pergent, L. Piazzi, M. Pirrotta, G. Relini, J. Romero, J. L. Sanchez Lizaso, R. Semroud, P. J. Schembri, A. Shili, A. Tomasello, and B. Velimirov. 2005. "Descriptors of Posidonia oceanica meadows: Use and application." Ecological Indicators:213-230.

Pranzini, Enzo, Lilian Wetzel, and Allan T. Williams. 2015. "Aspects of coastal erosion and protection in Europe." Journal of Coastal Conservation no. 19 (4):445-459. doi: 10.1007/s11852-015-0399-3.

Ranasinghe, Roshanka, Graham Symonds, Kerry Black, and Rob Holman. 2004. "Morphodynamics of intermediate beaches: a video imaging and numerical modelling 
study." Coastal $\quad$ Engineering no. 51 (7):629-655. doi: http://dx.doi.org/10.1016/j.coastaleng.2004.07.018.

ROM_0.3-91. 1991. Recommendation for Marine Works, Climate Action: Swell. Madrid, Spain: Puertos del Estado, Ministerio de Fomento.

Román-Sierra, Jorge, Juan j Muñoz-perez, and Marina Navarro-Pons. 2013. "Influence of sieving time on the efficiency and accuracy of grain-size analysis of beach and dune sands." Sedimentology no. 60 (6):1484-1497. doi: 10.1111/sed.12040.

Sedigh, Mahnaz, Rodger Tomlinson, Nick Cartwright, and Amir Etemad-Shahidi. 2016. "Numerical modelling of the Gold Coast Seaway area hydrodynamics and littoral drift." Ocean Engineering no. 121:47-61. doi: https://doi.org/10.1016/j.oceaneng.2016.05.002.

Semeoshenkova, Vera, and Alice Newton. 2015. "Overview of erosion and beach quality issues in three Southern European countries: Portugal, Spain and Italy." Ocean \& Coastal Management no. 118:12-21. doi: https://doi.org/10.1016/j.ocecoaman.2015.08.013.

Stive, Marcel J. F., H. J. de Vriend, R. J. Nicholls, and M. (1993) Capobianco. 1992. Shore nourishment and the active zone: A time scale dependent view. Paper read at Proceedings of the 23rd Coastal Engineering Conference, at Venice, Italy.

Stive, Marcel J. F., and Huib J. de Vriend. 1995. "Modelling shoreface profile evolution." Marine Geology no. 126 (1-4):235-248. doi: http://dx.doi.org/10.1016/0025-3227(95)00080-I.

Syvitski, James PM. 2007. Principles, methods and application of particle size analysis. Edited by James PM Syvitski. Cambridge, UK: Cambridge University Press.

Terrados, Jorge, and Carlos M Duarte. 2000. "Experimental evidence of reduced particle resuspension within a seagrass Posidonia oceanica meadow." Journal of Experimental Marine Biology and Ecology no. 243 (1):45-53.

Vacchi, Matteo, Giovanni De Falco, Simone Simeone, Monica Montefalcone, Carla Morri, Marco Ferrari, and Carlo Nike Bianchi. 2017. "Biogeomorphology of the Mediterranean Posidonia oceanica seagrass meadows." Earth Surface Processes and Landforms no. 42 (1):42-54.

van Rijn, L. C., D. J. R. Walstra, B. Grasmeijer, J. Sutherland, S. Pan, and J. P. Sierra. 2003. "The predictability of cross-shore bed evolution of sandy beaches at the time scale of storms and seasons using process-based Profile models." Coastal Engineering no. 47 (3):295-327. doi: http://dx.doi.org/10.1016/S0378-3839(02)00120-5.

Vellinga, P. 1984. "A tentative description of a universal erosion profile for sandy beaches and rock beaches." Coastal Engineering no. 8 (2):177-188. doi: http://dx.doi.org/10.1016/0378-3839(84)90012-7.

Vellinga, Pier. 1983. "Predictive computational model for beach and dune erosion during storm surges." Delft Hydraulics Laboratory.

Wang, Q.H. 2004. "Improvement on BP algorithm in artificial neural network." Journal of Qinghai University no. 22 (3):82-84. 